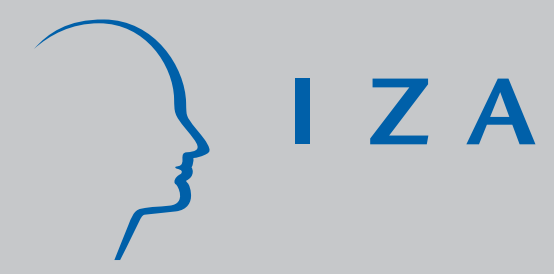

IZADP No. 1689

Women-Led Firms and the Gender Gap in Top Executive J obs

Linda A. Bell

July 2005 


\title{
Women-Led Firms and the Gender Gap in Top Executive Jobs
}

\author{
Linda A. Bell \\ Haverford College \\ and IZA Bonn
}

\section{Discussion Paper No. 1689 \\ July 2005}

\author{
IZA \\ P.O. Box 7240 \\ 53072 Bonn \\ Germany \\ Phone: +49-228-3894-0 \\ Fax: +49-228-3894-180 \\ Email: iza@iza.org
}

\begin{abstract}
Any opinions expressed here are those of the author(s) and not those of the institute. Research disseminated by IZA may include views on policy, but the institute itself takes no institutional policy positions.

The Institute for the Study of Labor (IZA) in Bonn is a local and virtual international research center and a place of communication between science, politics and business. IZA is an independent nonprofit company supported by Deutsche Post World Net. The center is associated with the University of Bonn and offers a stimulating research environment through its research networks, research support, and visitors and doctoral programs. IZA engages in (i) original and internationally competitive research in all fields of labor economics, (ii) development of policy concepts, and (iii) dissemination of research results and concepts to the interested public.
\end{abstract}

IZA Discussion Papers often represent preliminary work and are circulated to encourage discussion. Citation of such a paper should account for its provisional character. A revised version may be available directly from the author. 


\section{ABSTRACT \\ Women-Led Firms and the Gender Gap in Top Executive Jobs*}

Using data on Executive Compensation from Standard and Poor's ExecuComp, this paper explores the gender gap in top executive jobs and the effect of women CEOs, Chairs, and Directors on the pay of other women executives. The results show a narrowing of the uncorrected gender pay gap from the mid-1990s. Women top executives earn between $8 \%$ to $25 \%$ less than male executives after controlling for differences in company size, occupational title, and industry. The magnitude of the gender pay gap is statistically related to the gender of the Chief Executive and Corporate Board Chair. Women CEO and Board Chairs bring more top women and at higher pay than is found in non-women-led firms. Specifically, female executives in women-led firms earn between 10-20\% more than comparable executive women in male-led firms and are between 3-18\% more likely to be among the highest five paid executives in these firms as well. The paper thereby provides strong empirical evidence that women leaders are associated with positive outcomes for women executives in substantive and important ways.

JEL Classification: J11, J16, J33, J70, J71, J78

Keywords: executive compensation, gender discrimination, labor market institutions

Corresponding author:

Linda A. Bell

Haverford College

370 Lancaster Avenue

Haverford, Pa 19041-1392

USA

Email: Ibell@haverford.edu

\footnotetext{
* The author thanks Caitlin Coslett, Spencer Walters, and Donald Grunewald for outstanding research support throughout this project. Special acknowledgment is owed to Michael Bolton at Wharton Data Services for generously providing the data for this paper. I thank Robin Ely, Anne Preston, and seminar participants at Harvard Business School for helpful comments on an earlier draft.
} 
There is substantial theoretical and institutional support for the notion that women are more likely to be promoted into a particular job level and paid more in that job when there are a higher proportion of women already there and particularly in decision-making positions. The positive influence of women on other women's labor market outcomes can occur for a variety of institutional and theoretical reasons. First, women may pull women into firms and positions because they prefer to work with similar individuals, as consistent with the discrimination models developed by Becker (1957), or the organizational behavioral case-based and institutions-based literature (for example, Brass 1985, Ibarra 1992, Lincoln and Miller 1979). Second, as women advance through ranks, differences in the treatment of men and women that arise from imperfect information about women's abilities, as in "statistical discrimination" models (Phelps 1972, Aigner and Cane 1977) and "pollution" models of discrimination (Goldin 2002), will narrow as more and better individual specific information is obtained. Third, advancement of women may occur through mentoring which may pull women faster into organizational hierarchies, give women better access to job-specific human capital, and thereby increase their productivity and marketability, and the more-so the more senior are the women (Catalyst 1996, 2004, Preston 2004). Finally, networks may operate to the advantage of women if women have greater social ties to women than men (Ely 1994).

Traditionally, economic analyses of the gender pay gap and occupational segregation have focused on either gender differences in qualification, as in the human capital model (Mincer and Polachek 1974), or in the labor market treatment of similarly qualified individuals. While differences in labor market treatment may arise from discrimination, unmeasured differences -such as differences in effort, motivation, or skill - are often used to explain the residual impact of gender on earnings or promotion, 
especially where human capital is difficult to measure. The more homogeneous is the cohort of men and women the less important are unmeasured differences likely to be as an explanation for a gender pay or occupational attainment gap. A substantial body of literature has focused on comparing similar men and women based on educational attainment (as in Wood, Corcoran, and Courant 1993, for example) or on industry and job rank (as in Cohen, Broschak, Haveman 1998).

The best case therefore for estimating gender differences independent of quality is the case of workers with similar education, skills, and motivation. In this paper, I make use of Standard and Poor's ExecuComp database, which contains information on compensation for the top five executives for a large set of public companies of varying size. To the extent that top executive men and women share common ambition, skills and abilities as reflected in their professional success, top executives are an ideal group to use for exploring the gender gap in pay since unmeasured differences are likely to be small. Although female representation is low among top executives (on average 4.45 percent representation over the sample period), the representation of women has been increasing consistently through time and the data set is quite large (over 25,000 unique executives in the data). The gender gap in top executive pay is evaluated over time and after controlling for a variety of executive, firm, and industry specific factors.

This paper extends the work on the gender pay gap in top executive jobs in several ways. First, the executive gender pay gap is studied through 2003 , thereby extending analysis to a period of greater participation of women executives generally and specifically at higher ranks. Second, because of the large sample size of firms and the tripled representation of women at high levels in later years, I am able to test empirically the impact of women-leaders on the careers of other executive women. I do so by merging the ExecuComp data with an independent Institutional Investor Research Center (IRRC) data set on Corporate Directors. By combining the data in this way, I am 
able to differentiate between the effect of a woman-leader inside the firm and a femalefriendly corporate board. Exploiting the panel nature of the data using firm and individual-specific fixed effects further differentiates the role of female executives from female-friendly firms.

My results strongly support the view that women executives fare better in women-led firms. Specifically, women-executives working in women-led firms earn between $15-20 \%$ more in total compensation than women working in other firms after correcting for important executive, firm, and industry characteristics that might affect the magnitude of this relationship, and this effect appears even stronger in a sub-sample of women only using fixed-effects estimation methods. In addition, women-led firms have statistically significantly greater numbers of top women executives, suggesting that women-leaders help to bring women into the highest ranks of the firm. Firms with a relatively high representation of women Board members are also associated with positive outcomes for women executives.

Taken together, these findings support the contention that women leaders are instrumental to the success of top executive women in quantifiable and significant ways.

\section{The Gender Pay Gap among Top Executives}

\section{Means and Trends}

The key data set used in this analysis is Standard and Poor's ExecuComp data for the years 1992-2003. These data contain information on compensation and the individual components of compensation for the top five executives for all firms in the S\&P 500, S\&P Midcap 400, and S\&P Smallcap 600. In total, there are 2,194 unique firm observations and 25,529 unique executive observations over the twelve year period. These data are ideal for evaluating the gender gap in executive pay for a variety of reasons. First, the data offer information on different components of executive pay such 
as salary, annual bonus, long-term incentive bonus, and the value of stock options. Since salary is a more discretionary component of executive compensation than executive bonus which is often formulaic (Murphy 1999), it is reasonable to evaluate the gender pay gap in specific components of pay. Second, ExecuComp provides firmspecific information such as assets, market value, employment, stock price growth, and other financial variables for each firm-year observation and thereby allows the researcher to control for gender differences in pay that may arise from differences in the gender distribution of executives across firms by size or performance. Third, the ExecuComp data provides some limited information on each executive such as title, age, and tenure, as well as the detailed title of the executive, which allows for an investigation of the importance of pay differences independent of key executive characteristics. Fourth, the firms in the ExecuComp data constitute over $80 \%$ of the total market capitalization of US Public firms (Bebchuk and Grinstein 2005), and thereby offer the most broad view of the gender pay gap among top US executives in publicly traded firms. Finally, the large sample of firms allows for a test of the influence of the highest paid women on the career outcomes of the women below them, although women CEOs and Chairs constitute only a small share of the executive sample. Whereas empirical evaluation of the role of top women in the careers of women below them has tended to focus on specific firms and with limited data (Beckman and Phillips 2005, Cohen, Broschak, Haveman 1998), this data allows for a broad systematic study across widely varying firms and industries over time.

Table 1 summarizes key statistics on the representation of men and women executives, their relative pay, and their age and tenure from the ExecuComp data over the 1992-2003 period. Several facts emerge from the table. First, there are 1,369 unique observations of women top executives in these data and these women executives are younger and have less tenure on average than their male executive 
counterparts, consistent with other data and sources (Cappelli and Hamori 2004). Second, women are underrepresented at the highest rank of CEO and Chair and somewhat underrepresented at the President levels but are more likely to be Chief Financial Officers and General Counsels than are men. Gender differences in representation are in all cases statistically significant. Gender patterns by title are consistent with outcomes for the earlier period (Bertrand and Hallock 2001).

Table 2 looks at trends in the data over time. Column 1 of the table shows that the percent of top women executives has been increasing consistently through time, although at somewhat slower rate more recently. Column 2 shows that despite the low numbers of women CEO and Chairs (roughly 2 percent of the sample since 2000), their numbers have been increasing at roughly the same rate as the rate of increase in top women executives overall, and have nearly tripled since 1992. Column 3 shows that the percent of directors in the data that are female is roughly equal to the percent of CEOs and Chairs in the data that are female with similar upward trend. Columns 4 and 5 show the percentages of ExecuComp executives that are Board members by gender, and reveal that top executive men are twice as likely as women to be a corporate board director. This ratio has moreover, been roughly constant through the twelve year period covered by this data.

Table 3 looks at the raw gap in compensation between women and men executives using three measures of compensation, namely total gross compensation (salary plus bonuses, long-term and annual incentive pay, the Black-Scholes value of options, and the value of restricted stock), cash compensation (salary plus bonus), and salary. All compensation is expressed in 1992 real values. The raw gap in pay between men and women executives is $\$ 462,406$, and the ratio of female to male total compensation is .720 . The fact that the gender gap in compensation was significantly larger using the same data for 1992-1997 (Bertrand and Hallock 2001), indicates that the 
uncompensated gender gap in executive compensation has narrowed considerably through the late 1990 s and early 2000 s period. The gender gap in cash compensation is somewhat larger and in salary somewhat smaller than in gross compensation, and statistically significant in all cases.

\section{Regression Analysis}

Earlier empirical work on the gender gap in executive compensation using the ExecuComp data found that executive women earned $45 \%$ less than executive men, and that roughly $3 / 4$ of this gap was explained by two factors, namely that women work in smaller firms and are less likely to be CEO, Chair, or Company President (Bertrand and Hallock 2001). The analysis in this section updates this work.

The standard approach for analyzing the impact of gender on compensation is to evaluate the residual affect of gender on pay after controlling for characteristics of the individual, firm, and industry that might affect the way in which men and women are compensated by the firm. ${ }^{1}$ We know, for example, that women are relatively underrepresented in the top ranks of Corporate CEOs and Board Chairs (although their representation has been increasing through time), and that this adversely impacts their relative pay. We know as well that women are under-represented in larger firms and in high-paying industries like financial services (Bertrand and Hallock 2001). In any case, there is a great deal of heterogeneity in pay practices across firms (Murphy 1999) that must be accounted for when determining pay.

Table 4 looks at the uncorrected- and corrected-gender gap in executive pay using the updated ExecuComp data through 2003. The dependent variable for the first four columns of Table 4 is the natural log of real gross compensation, a measure which

\footnotetext{
${ }^{1}$ See for example Blau, Ferber, and Winkler (2002) for a thorough summary of the voluminous literature on this topic.
} 
includes the sum of salary, annual incentive bonus, longer-term bonuses, and the value of options and restricted stock. Column 5-8 of the table use the natural log of real salary (columns 5-6) and salary plus annual bonus (columns 7-8), in order to test for gender differences by component of executive pay.

Column 1 shows that there is a $25.4 \%$ difference in the gross compensation of male and female top executives in these data. This is substantially smaller than the $45 \%$ difference reported by Bertrand and Hallock (2001) for 1992-1997. The decline in the gender gap in executive compensation is consistent with a decline in the gender pay gap more generally over this period (Blau and Kahn 2000). Column 2 adds controls for firm size and valuation (employment and real market capitalization), for occupational title (for CEO or Chair), as well as fixed effects for industry and year. The gender pay gap falls to $10.8 \%$ after the inclusion of these variables. Consistent with the theory, the elasticity of compensation with respect to firm-size is roughly .35 and is statistically significant in all cases (Murphy 1999). Column 3 uses detailed occupational titles controls ${ }^{2}$ and this reduces the unexplained gap to 7.8 percent. Grouping of executive titles is tenuous in that grouping is difficult and titles convey different responsibility and status across firms. In addition, if women are less likely to be offered a high-powered title than comparable men (and commensurate of course with responsibility and pay), then the inclusion of these detailed titles may result in an underestimation of the true magnitude of the gender pay gap. The inclusion of age (column 4) leaves the results qualitatively unchanged, but

\footnotetext{
${ }^{2}$ Occupational categories were constructed based on the "executive title" variable in ExecuComp. There are more than 6,000 unique occupational titles in the data, so the construction of these controls was quite cumbersome. While certain executive titles were easily converted and grouped (such as "vice president" and "vp" and "vice pres"), other groupings were significantly more complicated. In cases where executives were given two titles, the executive's highest rank in title (based on average pay) was used. From the ExecuComp data the following titles were constructed: CEO, CEO and Chair, CEO and Vice-Chair, CEO and President, Chair, Vice Chair, President, Chief Financial Officer, Chief Operating Officer, Chief Accounting Officer, Chief Technology Officer, Chief "Other" Officer, General Counsel, Controller, Senior Executive Vice President, Executive Vice President, Senior Vice President, General Vice President, and VicePresident. All other titles were treated under type "All Other."
} 
reduces the number of observations by over 50 percent, and age is therefore excluded from the reported analysis that follows. ${ }^{3}$ In sum, the estimates suggest that between 7$11 \%$ of the gender gap in executive compensation is unexplained.

Columns 5-8 of Table 4 report results for real salary and cash compensation (salary plus bonus) and reveal a similar gap between the pay of top women and men executives in the range of $10-13 \%$ after correcting for firm size, time, industry, and title.

In sum, the regression results reveal several important facts. First, the uncorrected gender gap in compensation among top corporate executives, while large (roughly 25\%), has narrowed considerably over time as women executives increased their representation among top corporate executives at all ranks. Second, firm size and the under-representation of women at CEO, Chair and other executive titles explains about $50-60 \%$ of the differences in pay, less than the $75 \%$ contribution cited by Bertrand and Hallock (2001) over the 1992-1997 period. Finally, after controlling for firm size, executive title, industry, and time, there remains a substantial gap (7-13\%) in the pay of top executive women that is true for all components of pay. ${ }^{4}$

\section{Statistical Discrimination and the Role of Unmeasured Human Capital Factors}

The traditional approach to explaining the residual gender gap in pay has been to focus on either differences in the unmeasured qualifications by gender or on differences in their market treatment. Gender differences in qualifications presumably result from differences in human capital that might derive from acquired endowments (education

\footnotetext{
${ }^{3}$ Robustness tests for the effect of both age and tenure (which reduces the number of observations by $65 \%$ show no qualitative impact of either variable on the magnitude or significance of the gender pay gap in any of the reported regression results.

${ }^{4}$ Bertrand and Hallock (2001) find a gap of similar magnitude over the earlier period using roughly the same specification. After controlling for age and tenure (and reducing the number of observations from over 42,000 to just over 7,000 ), they find that the unexplained gender compensation gap falls to below 5 percent and is no longer statistically significant. These results are difficult to interpret however, as in the case here, because they are imprecisely estimated with a small sample that is not necessarily random with respect to the population of executives in the data base.
} 
and job-training), or other more difficult to measure factors (ambition or motivation). The reasonable presumption in this particular case -- a unique sample of top-paid public company executives - is that unmeasured differences in both endowment and motivation are small and don't account for unexplained gender differences in compensation. Indeed, it is certainly possible that, if anything, the women in this sample are even more motivated than the men in that they have succeeded against presumably greater odds.

In any case, while data on education and motivation are not available on a broad basis for the women and men executives in my sample, I was able to obtain some information on education for a sub-sample of executives that sheds some limited light on the magnitude of any difference. Specifically, I obtained information on education and career/family decisions for a sub-sample of 3054 men and 296 women executives in the ExecuComp data through online sources such as Forbes, Hoover, and Lexis-Nexus, as well as archived company websites. ${ }^{5}$ The data in Table 5 are unremarkable in that except for the greater tendency of executive men in the sample to obtain MBA degrees and of women to obtain JD degrees there are small and statistically insignificant differences in the educational experiences of the men and women executives in all cases. ${ }^{6}$ The point is that to the extent that these results hold up to a larger sampling of executives across industry differences in education are not surprisingly unlikely to explain the observed gap in pay.

\footnotetext{
${ }^{5}$ Women were over-sampled in this application, as were executives in the technology and financial services sector. Note as well that the education-specific data over-samples executives from 2002 and 2003 since data for the most recent executives is more readily available.

${ }^{6}$ Since the education-linked data over-sample financial services executives and given the greater tendency of financial services executives to obtain MBAs and the smaller percentages of female executives in financial services (about $2.5 \%$ of the financial services executives) the higher frequency of MBAs among male executives may be somewhat overstated.
} 


\section{Women-Led Firms and the Impact on Women Executives}

The under representation of women executives on corporate boards and in the highest corporate positions has been well documented elsewhere (see for example, Catalyst 2000, 2003), and at least some of the implications of this gap are well understood. Indeed, Bertrand and Hallock (2001), using ExecuComp data through 1997, show that $47 \%$ of the mean difference in the overall compensation of top women and men executives can by explained by the scarcity of women in the top four occupations of Chair, CEO, Vice Chair, and President.

Is there a spillover effect to other lower-ranked women executives associated with the under-representation of women in the ranks of Chair/CEO and on Corporate Boards?

Tables 6 and 7 begin to address this issue in the simplest of terms, looking at the means of salary, total cash compensation, and total gross compensation, for women and men in companies that are "led" by women executives as compared with those that are not. "Women-led companies" are defined in one of two ways. The less restrictive definition defines women-led companies to be those with a CEO and/or Chair who is a woman. A somewhat more restrictive definition imposes the additional constraint that the female CEO leader be a member of the Corporate Board. ${ }^{7}$ Since top corporate compensation (and promotion decisions) are usually discussed and determined through an internal-process before subsequent recommendation to the compensation committee of the board (Murphy 1999), the CEO has obvious influence at both internal and Boardstages and is therefore more likely to be determinative of outcome when she sits on the Corporate Board. Also, there is evidence that women directors are accepted as legitimate leaders more often than women in other top positions due to the relatively

\footnotetext{
${ }^{7}$ There are 79 women executives in the data set who are CEOs or Chairs of their firms. Of these 79 women, 29 also hold a title on the Board of Directors.
} 
greater prevalence of women directors and additional evidence that this greater acceptance increases their influence (Beckman and Phillips 2005).

Table 6 shows that women fare better in terms of salary and total cash compensation in female-led companies where the CEO and/or Chair is female. The difference in pay between women executives in female-led and other firms is statistically significant in all cases, and exceeds the differences in male pay in female-led and other firms in all cases as well. The top row of the table shows that the unadjusted difference between the salary of women and male executives in female-led and other firms is $\$ 126,693$, a greater than $50 \%$ premium to women in women-led firms. The difference to men in women-led and other firms is considerably smaller (Row 2). Row 4 of the table excludes all executives with the title of CEO and/or Chair from the analysis since the female-led firm is defined in this way and to avoid over-sampling of the highest paid women. As is clear from the analysis, the difference between female salaries in femaleled and other firms is still statistically significant and large, exceeds the difference in salary to men in female-led and other firms, and indicates a roughly $13 \%$ premium to women in women-led firms. Rows 7 and 8 of the table perform the same analysis using real cash compensation (salary plus incentive bonus), and show that using this measure of compensation, women continue to fare relatively better in women-led companies. Not surprisingly, the magnitude of the relative advantage is smaller in the case of cash compensation (10.9\%), since salary is a more discretionary component of pay than is the executive performance bonus (Murphy 1999). Finally, rows 10 and 11 complete the analysis using total gross compensation as the measure of pay and show a nearly $\$ 300,000$ advantage to women in women-led firms that is nearly twice as big as the advantage to men.

Table 7 performs the same analysis using the more restrictive definition of a female-led company that restricts the female CEO to be a member of the Corporate 
Board. The results are qualitatively unchanged, in that women in women-led companies enjoy a pay premium in salary and total compensation that does not extend to men. It is interesting that in women-led companies in this more restrictive case (where women leaders arguably have greater control over compensation by virtue of both title and board stature), there is no statistical difference between what female and male top executives are paid.

The literature suggests that women executives support other women not exclusively in terms of better relative pay, but in terms of representation and positions as well. To what extent then do the data support the claim that women-leaders bring more women executives to top positions in their company?

Table 8 begins to answer this question by comparing women-led firms and the incidence of women executives. The uncorrected results lend impressive support to the claim that women-leaders help women beneath them to rise to the top of the corporate ranks. Row 1 shows that the incidence of top women corporate executives is over fourtimes greater in women led companies than in male led companies in the ExecuComp data. Row 2 excludes all executives with the CEO and/or Chair title (since women-led companies are defined this way) and shows that in this case, women are still over twotimes more likely to rise to the top of their corporations in firms in which women are the decision makers. Rows 3 and 4 of the table show that the same trends emerge when the more restrictive definition of a women-led company is applied. It is perhaps worth noting that in the more restrictive case where the influence of the women-leader is higher by virtue of her Board representation (Rows 3 and 4), there are even more women in the top-five ranked executives in terms of pay (compared with Rows 1 and 2), and that this difference in affect is statistically significant in all cases.

\section{Multivariate Analysis}


While there is a considerably body of case-based evidence suggesting that top women can be critical for the success of women below them (Cohen, Broschak, Haveman 1998, Catalyst 1996, 2002, Beckman and Phillips 2005), the empirical economics literature finds little evidence of a positive effect of women mentoring women (Canes and Rosen 1995, Neumark and Gardecki 1998, Preston 2004), although the importance of white-male mentoring in perpetuating segregation in the workplace is wellunderstood at a theoretical level (Athey, Avery, and Zemsky 2000).

To better evaluate the significance of women on the careers of women below them independent of other factors, I rerun the regressions in Table 4 including an interaction term for females that work in female-led companies. These results are presented in Table 9. Column 1 of the Table shows a clear compensation advantage to women in firms with a female CEO and/or Chair of $46.5 \%$ percent which fully compensates for the $34.1 \%$ pay disadvantage to women generally. Column 2 of the table controls for firm size and valuation, CEO/Chair Occupational Title, Year, and Industry, and shows a continued positive effect for females working in a female-led company of 8.0 percent. Column 3 adds detailed occupational controls which reduces the magnitude and statistical significance. If women executives are disadvantaged in title/occupational attainment within firms or if women-leaders more readily promote talented women into higher titled positions, then the inclusion of detailed occupational controls may lead to an under-prediction of the effect of women-led companies on executive women's wages.

Columns 4 and 5 provide robustness checks on the results above. Specifically, Column 4 excludes all CEO/Chairs from the analysis and thereby looks at the effect of a woman CEO/Chair on all other employee wages. The table shows a continued positive effect for females working in a female-led company of 8.5 percent, although this effect is statistically significant at only $90 \%$ confidence levels. Column 5 controls for the 
executives age (which is available for only a sub-sample of the executives) and shows an even bigger impact on women of working in female-led companies after controlling for age.

Columns 6-10 of the table perform the same analysis using the more restrictive definition of female-led firms that includes leadership in the firm (CEO) and membership on the Board. Not surprisingly, the impact on women of working in women-led companies is stronger in magnitude and in significance using this definition and offers qualitatively similar conclusions.

The literature suggests that women-leaders are instrumental in promoting women within the organization (Cohen, Broschak, Haveman 1998, Beckman and Phillips 2005, Athey, Avery, and Zemsky 2000). To test this effect, I use the women-led company dummy variable as a proxy for the effect of having a women decision maker in the top ranks of the firm, and the female executive dummy variable as a measure of the representation of top ranked - among the highest five paid - women executives in these firms. Roughly four and a half percent of the executives in ExecuComp are female. The difference in the percentages of female executives in women-led companies as opposed to male-led companies can therefore be estimated after controlling for characteristics of the firm or industry that might influence the presence of women executives at the firm.

Table 10 presents the results from a probit-analysis of the dichotomous female variable. All coefficients are the probability of a female executive in the company evaluated at the mean of the independent variable. The odd-numbered columns include only the female-headed company dummy variable using the less-restrictive (columns 14) and more-restrictive (columns 5-8) definitions, and excluding executives with the CEO/Chair title (Columns 3 and 7). The even numbered columns give results with the inclusion of specified covariates. The specifications for the regressions using the two definitions of female-headed firms use identical covariates. 
The results show strong evidence that there are more women executives in women-led firms. In all models, top women were significantly more likely to be in women-led firms. The exclusion of executives with the CEO and Chair title from the analysis dilutes the effect of women-leadership in the firm since women are overrepresented in this group by virtue of how these firms are assigned. The estimates defining women-led firms based on the title of CEO or Chair without accounting for Board membership (columns 1-4) suggest that women-leaders increase the probability of other top ranking women in the firm from between $13.3 \%$ to $3.3 \%$, depending whether CEOs and Chairs are omitted from the sample for analysis and whether firm size, year, industry, and detailed occupation, is added as control.

The estimates using the more restrictive definition of women-led firms in which the female CEO is also a Board member (columns 5-8) are somewhat stronger for the overall impact of women-leaders on other top women at the firm. Specifically, the results show that the presence of a woman CEO who is also a director increases the probability that women will be in the top-five paid executives in the firm by between $17.5 \%$ and 4.2\% depending on sample and covariates.

In sum, the empirical evidence shows that women who work in women-led firms are compensated higher and more likely to be in the top-five paid executives in the firm than are comparable women in non-women-led firms.

\section{Firm Board Structure}

There are several possible explanations for the statistically strong link between women-led firms and the positive compensation and representation effects on the women that work in them. It has been observed, for example, that a high and increasing proportion of women in a firm may lead to more women in that firm and especially when the women are in high positions. This may occur for at least three reasons. First, 
women may obtain more human capital and better access through mentoring (Catalyst 1996, 2004, Preston 2004). Second, the distaste (and discrimination) for women as coworkers may fall as their proportion rises (Becker 1957). Third, better information about women may correct informational biases and asymmetries that lead to more hiring and promotion of women in high ranks (Phelps 1972, Aigner and Cane 1977, Goldin 2002).

To the extent that the there is better mentoring of women in women-led firms, it should be the case that the positive relationship between female compensation/representation and women-led firms is independent of other factors that might influence the pay and numbers of female executives in these firms. For example, firms with a relatively high proportion of women executives tend to be younger and to have flatter hierarchies (Capelli and Hamori 2004) and this may influence the relative pay and representation of women. Similarly, it is reasonable to assume that firms with a relatively high representation of women on their corporate board will have more women executives since the presence of high-level women is important for the outcomes of other women (Beckman and Phillips 2005). If a high share of women corporate board members is also positively correlated with the probability of a women-leader at the firm, then the omission of board demographics may lead to spurious conclusions on the effects of the women-leader.

Data on the share of female directors on the Corporate Board was obtained from the IRRC and made available through Wharton Data Services. These data, available from 1997-2001, contain valuable information on Corporate Board representation such as gender, insider-outsider status, age, and committee responsibilities. From these data I was able to construct a variable that measures the share of female executives on the corporate board in each firm annually from 1997-2001. Since the representation of women on corporate boards has increased through time, I retain the annual component 
of the data, and merged the director's data by company and year with the ExecuComp data. $^{8}$

The full merged database therefore contains information from the two sources, namely compensation data and data on company size and executives from ExecuComp, and data on directors measured at the company and year level and available from the IRRC from 1997 to 2001.

What effect then, if any, does the gender composition of a firm's Board have on the pay and representation of top women executives?

To begin to analyze this question, Tables 11 looks at the average values of compensation and female representation in firms with a high-share of female directors (in the top-quartile with greater than $13.33 \%$ female directors), and those with no female directors (in the bottom quartile of firms). Table 11 shows a clear effect of the share of female directors and the high-level representation of its top female executives, although the effect of board composition on female pay is somewhat more ambiguous. For example, while there is over twice the representation of top female executives on firms that have a high-share of corporate directors than on those that have none, the differences in pay to women executives in the two types of firms is not significant. While women are paid over $\$ 800,000$ more in firms with a high share of female board members men are paid over $\$ 975,000$ more in these firms, implying that the differences between the pay of men and women in companies with a high share of women board members are even larger than in firms with no female members.

\section{Gender Compensation Differences}

\footnotetext{
${ }^{8}$ Data were merged by CUSIP number. There were missing data for 734 ExecuComp firms for the 1997-2001 period.
} 
The obvious next step is to evaluate the effect of the gender composition of the board on the relationship between female-led firms and both female executive compensation and representation. Table 12 evaluates the impact of female-leadership on the compensation of female executives after controlling for the gender composition of the board of directors of the firm, as well as other covariates analyzed above. Column 1 shows that while top women executives in general earn $40 \%$ less than comparable men, this disadvantage is erased for female executive in female-led firms. The estimates further suggest that if the share of female board members increases by one percentage point the impact will be to increase salary by 2.20 percent, a large effect consistent with the results from the means tables above. The results show that there is no effect on women who work in firms with a high share of female directors after controlling for the female-led firm interaction.

Columns 2-5 perform the same analysis adding various covariates. Column 2 presents the results after adding controls for year, industry, and firm size. In this case, the effect of working in a female-led company for women remains qualitatively unchanged. The interaction on the firm's share of female directors shows that female representation on the board works to the advantage of women executives, who enjoy a premium over women working in companies with low female board representation. ${ }^{9}$ Columns 3 and 4 add controls for aggregated (controlling for CEO and Chair positions) and detailed occupation respectively, and show that the positive impact of female-led firms on the pay of female executives is not independent of occupational title as defined in this way, although the impact of female board member share on female executive pay appears independent of title at least in the aggregated case (column 3). Finally, column

\footnotetext{
${ }^{9}$ The mean on the share of female directors is .081 . A doubling in the share of female directors in the firm from $8 \%$ to $16 \%$ would in this case, imply an increase in the compensation of women in these firms of 4.5 percent.
} 
5 of the table omits all executives with the title of CEO and Chair from the analysis after the addition of all covariates with qualitatively similar results.

Columns 6-9 of the table employ the more restrictive definition of women-led firms. As before, the positive impact on women executives of working in women-led firms is stronger, ranging from a $60 \%$ advantage after controlling for company size, year, and sic (column 6) to a $13.6 \%$ advantage (column 9) after accounting for characteristics of the firm, year, industry, detailed occupational title, and after omitting all executives with the title of CEO and Chair from the analysis. Similarly the results show that female executives in firms with a high share of female board representatives fare better than other female executives.

In sum, the empirical results in Table 12 suggest the following. First, there is considerable evidence that women executives earn higher pay when they work in firms in which there is a female CEO or Chair. Second, the impact of women-leaders on top women executives seems to be related at least in part to the fact that women who work in women-led firms are promoted more readily into higher paying occupations, since the inclusion of detailed occupation impacts the magnitude and in some cases the statistical significance of both the female-led company and share of female director interactions. Third, women executives also earn higher pay when they work in firms that have a greater representation of women on their corporate board. The magnitude of the coefficients implies that if the share of women on the corporate board was doubled from its mean of .08 , the compensation of women in these firms would increase by between 3.6 and 5.1 percent. Finally, the positive impact on women executives of working in a female-led company and/or in a company that has a high proportion of female board members is robust to the exclusion of the top CEOs and Chairs where the impact might, of course, be expected to be the greatest. 
Women Leaders v. Women-Friendly Firms

While the persistently strong impact of women-leaders suggests that womenleaders are helping the women below them, the possibility remains that it is "womenfriendly" firms and not the female corporate heads that are responsible for the positive gender results. For example, if women-friendly firms are more likely to have both a woman CEO and/or Board Chair and more top women employees at higher pay, then the association between women-leaders and the gender pay gap might be due to unmeasured characteristics of companies and incorrectly attributed to the leaders that head them.

To test for the potential impact of "women-friendly" companies, Table 13 presents estimates from regressions using firm and individual fixed effects, and thereby abstracting from characteristics of firms that may be associated with executive pay and from the effect of individual executive leaders on executive pay during and after their tenure as chief executive or chair. Columns 1-2 present the company fixed effects estimates and Columns 3-4 present the individual fixed effects estimates. The fixed effects results lend strong empirical support to the documented empirical finding that women-leaders increase the pay of women executives since the female-led firm interactions are statistically significant in both firm and individual fixed effects when excluding the CEOs and Chairs.

What do the results from Tables 12 and 13 imply, if anything, about the role of women-leaders in the careers of other top women executives? Since the impact on top women executives of working in a female-led company is in most cases independent of the gender composition of the board (Table 12), and of unmeasured characteristics of firms and individual leaders over time (Table 13), the results offer one clear conclusion, namely, that women-leaders play a critical equalizing role in the compensation received by other women executives who are fortunate to work for them. 


\section{Gender Representation Effects}

Does the presence of women board members imply greater numbers of women executives? Table 14 presents the results from a probit-analysis similar to that above, but adding additional covariates for the firm's female representation on its board. Coefficients are the probability of a female executive in the company evaluated at the mean of the independent variable. Odd-numbered columns include the female-headed company dummy variables and the female director variable. Even numbered columns add controls for firm-size and market capitalization, industry, year, and executive title.

The results offer consistent and strong confirmation that women executives are more likely to fare better in companies that are headed by a female CEO/Chair. The impact of a female-led company on the probability that a woman will be among the top five highest paid executives in the company ranges from between $13 \%$ and $2.4 \%$ depending on the definition of female-led company and the various covariates, but these effects are statistically significant at greater than the $99 \%$ level in all cases. Similarly, a high proportion of female board directors impacts positively the probability of a top woman executive in the firm. The implied magnitude of the coefficients suggests that a doubling in the share of female directors from its mean of .08 to .16 would increases the representation of women at the top of the firm by $1 \%$ to $1.6 \%$, and this effect is statistically independent of the characteristics of the firm, industry, and executive title in all cases. Finally, democratic companies have a greater representation of top female executives, and while small in magnitude, the impact of democratic structure is statistically significant in all cases.

In sum, OLS, fixed effects, and probit results are broadly consistent with the view that women decision makers (CEOs, Chairs, and Directors) help the women working beneath them. 


\section{Conclusions and Implications}

This paper has documented several important facts. First, using a data set of the highest 5 ranking executives in a sample of publicly traded firms shows that top women executives are paid between $8 \%$ to $25 \%$ less than male executives, and that this effect is statistically independent of characteristics of the firm (market valuation, employment), executive (age, tenure, and title), and industry known to influence compensation. To the extent that these executives are similar in their educational background and motivation, and to the extent that women executives may face hurdles that exceed those faced by men, it is unlikely that much of this gap can be explained by unmeasured differences in human capital.

Second, the results offered here present strong evidence in support of the notion that women executives fare better - both in terms of their relative compensation and numbers - in companies that have a female CEO or Chair and especially if the female CEO is a member of the Board. This effect is statistically significant in nearly all cases, and is independent of important characteristics of the executive, firm, and industry that are known to influence compensation and representation by rank.

Third, there is a statistically strong link between the share of female board directors in the company and the relative compensation and representation of women executives.

The fact that top women executives fare better in firms that are led by women either internally or at the board level is at least consistent with the argument that the help of women by women is an important factor in the career outcomes of women. To judge how much weight should be placed on this interpretation, it must of course be compared to alternative reasons for the observed correlations. 
One alternative interpretation of the link between women's outcomes and the female leadership of the firm is that it reflects not a mentoring or supporting relationship per se, but instead the degree of "women-friendliness" of the firm. It is certainly possible, for example, that women-friendly firms might have greater numbers of women executives and offer them better pay, while at the same be more likely to have greater numbers of women board members and a women CEO. The association between female leadership and representation and compensation might not be causal in this case. As best as the data allow, this does not appear to be what is going on. Instead, the empirical evidence strongly supports that working in a female-headed is good for female executives independent of the characteristics of the firm.

A second plausible interpretation of the link between women-led firms and the outcomes for women executives is that higher quality women are sorted into women-led firms. If for example, women prefer working in women-led firms, and therefore a greater numbers of high-quality women are drawn to these firms, then differences in the pay of women in women-led firms might reflect differences in the ability/productivity of these higher quality women. There is no evidence to support sorting of this kind. Indeed, while an industry like apparel and retail has a relatively high representation of women executives, the industry is generally not associated with high pay or an especially highskilled workforce, although it is associated with a great deal of uniformity in pay.

Indeed, there is very strong empirical evidence supportive of the fact that women leaders are associated with positive compensation outcomes and for bringing women to the highest ranks of the corporate hierarchy. It seems a logical conclusion to infer that women-leaders are important to the careers of women below them. If equity for highskilled executive women is a policy goal then the one obvious instrument is affirmative action at the very top of the corporate hierarchy. 


\section{REFERENCES}

Arrow, Keneth (1972). Models of Job Discrimination. New York: Lexington Books.

Athey, Susan, Christopher Avery, and Peter Zemsky (2000). "Mentoring and Diversity." American Economic Review 90 (4), pp. 765-86.

Baron, James N., Michael T. Hannan, Greta Hsu, and Ozgecan Kocak (2003). "In the Company of Women: Determinatns of the Gender Mix in Young High-Tech Firms." Mimeo, Stanford University, June.

Bebchuk, Lucian and Yaniv Grinstein (2005). "The Growth of US Executive Pay," Mimeo, January.

Bebchuk, Lucian, Alma Cohen, and Allen Ferrell (2004). "What Matters in Corporate Governance?" Harvard Law School Discussion Paper No. 491, September.

Becker, Gary. The Economics of Discrimination (1971). Chicago: Chicago University Press.

Becker, Gary (1985). "Human Capital, Effort, and the Sexual Division of Labor." Journal of Labor Economics, 3 (1, part 2), pp. S33-S58.

Beckman, Christine M. and Damon J. Phillips (2005). "Interorganizational Determinants of Promotion: Client Leadership and the Attainment of Women Attorneys." Mimeo, February.

Bertrand, Marianne and Kevin F. Hallock (2001). "The Gender Gap in Top Corporate Jobs," Industrial and Labor Relations Review, Vol. 55, No. 1, October.

Blair-Loy, Mary (1999). "Career Patterns of Executive Women in Finance: An Optimal Matching Analysis." American Journal of Sociology, Vol. 104, No. 5, March, pp. 134697.

Blair-Loy, Mary (2001). "Cultural Constuctions of Family Schemas: The Case of Women Finance Executives." Gender and Society, Vol. 15, No. 5, October, pp. 687-709.

Blau, Francine and Lawrence Kahn (2005). "Changes in the Labor Supply Behavior of Married Women: 1980-2000," NBER Working Paper No. 11230, March.

Blau, Francine and Lawrence Kahn (2000). "Gender Differences in Pay," Journal of Economic Perspectives, Vol. 14, No. 4, Autumn, pp. 75-99.

Blau, Francine, Marianne Ferber, and Anne Winkler (2002). The Economics of Women, Men, and Work. New Jersey: Prentice Hall, $4^{\text {th }}$ edition.

Capelli, Peter and Monika Hamori (2005). "The New Road to the Top." Harvard Business Review, January. 
Capelli, Peter and Monika Hamori (2004). "The Path to the Top: Changes in the Attributes and Careers of Corporate Executives, 1980-2001," NBER Working Paper No. 10507, March.

Cohen, Lisa E., Joseph P. Broschak, and Heather A. Haveman (1998). "And Then There Were More? The Effect of Organizational Sex Composition on the Hiring and Promotion of Managers." American Sociological Review, Vol. 63, October.

Ellwood, David, Ty Wilde and Lily Batchelder (2004). "The Mommy Track Divides: The Impact of Childbearing on Wages of Women of Differing Skill Levels," Harvard University Mimeo, March.

Fuchs, Victor (1989). "Women's Quest for Economic Equality." Journal of Economic Perspectives, Vol. 3, No. 1, Winter, pp. 25-41.

Goldin, Claudia (2002). "A Pollution Theory of Discrimination: Male and Female Differences in Occupations and Earnings," NBER Working Paper No. 8985.

Gompers, Paul A., Joy Ishii, and Andrew Metrick. "Corporate Governance and Equity Prices, Quarterly Journal of Economics, Vol. 118, No. 1, February, pp. 107-155.

Murphy, Kevin J. (1999). "Executive Compensation," in Orley Ashenfelter, ed., Handbook of Labor Economics, Vol. 3, North Holland.

Preston, Anne (2004). Leaving Science: Occupational Exit from Scientific Careers. New York: Russell Sage Foundation.

Waldfogel, Jane (1997). "The Effect of Children on Women's Wages." American Sociological Review, Vol. 62, April, pp. 209-217.

Waldfogel, Jane (1998). "Understanding the 'Family Gap' in Pay for Women with Children." Journal of Economic Perspectives, Vol. 12, No. 1, Winter, pp. 137-156. 
TABLE 1. CHARACTERISTICS OF THE EXECUCOMP DATA ${ }^{1}$

\begin{tabular}{|c|c|c|c|}
\hline & All Executives & Women Executives & Men Executives \\
\hline $\begin{array}{l}\text { Number of Unique } \\
\text { Executives }\end{array}$ & 25,529 & 1,369 & 24,160 \\
\hline Average Age & $\begin{array}{l}53.18 \\
(.135)\end{array}$ & $\begin{array}{l}49.00 \\
(.526)\end{array}$ & $\begin{array}{l}53.38 \\
(.138)\end{array}$ \\
\hline Average Tenure & $\begin{array}{c}10.048 \\
(.054)\end{array}$ & $\begin{array}{l}6.454 \\
(.188)\end{array}$ & $\begin{array}{l}10.217 \\
(.056)\end{array}$ \\
\hline \multicolumn{4}{|c|}{ Percent with Title } \\
\hline Chair and/or CEO & $\begin{array}{c}9.33 \\
(.182)\end{array}$ & $\begin{array}{l}2.34 \\
(.409)\end{array}$ & $\begin{array}{c}9.73 \\
(.191)\end{array}$ \\
\hline President & $\begin{array}{l}15.86 \\
(.229)\end{array}$ & $\begin{array}{l}12.64 \\
(.898)\end{array}$ & $\begin{array}{l}16.05 \\
(.236)\end{array}$ \\
\hline Chief Financial Officer & $\begin{array}{l}11.25 \\
(.112)\end{array}$ & $\begin{array}{l}14.10 \\
(.941)\end{array}$ & $\begin{array}{l}11.09 \\
(.202)\end{array}$ \\
\hline Chief Operating Officer & $\begin{array}{c}2.48 \\
(.097)\end{array}$ & $\begin{array}{c}1.46 \\
(.324)\end{array}$ & $\begin{array}{c}2.53 \\
(.101)\end{array}$ \\
\hline General Council & $\begin{array}{c}4.68 \\
(.132)\end{array}$ & $\begin{array}{l}10.01 \\
(.811)\end{array}$ & $\begin{array}{c}4.38 \\
(.132)\end{array}$ \\
\hline \multicolumn{4}{|c|}{ Percent with Pay Rank } \\
\hline Rank 1 (Highest Pay) & $\begin{array}{c}9.14 \\
(.180)\end{array}$ & $\begin{array}{l}2.78 \\
(.262)\end{array}$ & $\begin{array}{c}9.50 \\
(.189)\end{array}$ \\
\hline $\begin{array}{c}\text { Rank Below } 5 \text { (Lowest } \\
\text { Pay) }\end{array}$ & $\begin{array}{l}2.83 \\
(.104)\end{array}$ & $\begin{array}{c}4.46 \\
(.558)\end{array}$ & $\begin{array}{c}2.74 \\
(.105)\end{array}$ \\
\hline
\end{tabular}

\footnotetext{
${ }^{1}$ Source: Standard and Poor's ExecuComp Data, 1992-2003 with partial year data through Q3 for 2003.
} 
TABLE 2. REPRESENTATION OF WOMEN EXECUTIVES BY YEAR, 1992-2003¹

\begin{tabular}{|c|c|c|c|c|c|}
\hline & $\begin{array}{l}\text { Percent of } \\
\text { Top } \\
\text { Executives } \\
\text { That Are } \\
\text { Female }\end{array}$ & $\begin{array}{c}\text { Percent of } \\
\text { CEO/Chair } \\
\text { Title That } \\
\text { Are Female }\end{array}$ & $\begin{array}{l}\text { Percent of } \\
\text { Directors } \\
\text { That Are } \\
\text { Female }\end{array}$ & $\begin{array}{l}\text { Percent of } \\
\text { Female } \\
\text { Executives } \\
\text { that are } \\
\text { Directors }\end{array}$ & $\begin{array}{c}\text { Percent of } \\
\text { Male } \\
\text { Executives } \\
\text { That Are } \\
\text { Directors }\end{array}$ \\
\hline 1992 & 1.67 & 0.61 & 0.91 & 18.66 & 30.90 \\
\hline 1993 & 2.08 & 0.65 & 0.96 & 16.67 & 28.67 \\
\hline 1994 & 2.80 & 0.79 & 0.97 & 11.71 & 27.76 \\
\hline 1995 & 3.47 & 0.96 & 1.15 & 10.85 & 27.89 \\
\hline 1996 & 3.83 & 1.13 & 1.37 & 11.61 & 27.88 \\
\hline 1997 & 4.29 & 1.15 & 1.45 & 10.64 & 27.50 \\
\hline 1998 & 4.72 & 1.40 & 1.66 & 10.72 & 26.84 \\
\hline 1999 & 5.32 & 1.93 & 1.94 & 10.94 & 25.97 \\
\hline 2000 & 5.82 & 2.01 & 2.10 & 10.73 & 25.62 \\
\hline 2001 & 6.32 & 2.15 & 2.28 & 10.37 & 24.76 \\
\hline 2002 & 6.35 & 2.10 & 2.37 & 10.92 & 25.05 \\
\hline $2003^{2}$ & 6.18 & 2.16 & 2.45 & 12.42 & 25.99 \\
\hline $\begin{array}{c}\text { Unique } \\
\text { Observations }\end{array}$ & 1,369 & 84 & 147 & 147 & 4,476 \\
\hline Average & 4.45 & 1.39 & 1.61 & 11.39 & 27.02 \\
\hline
\end{tabular}

${ }^{1}$ Source: Standard and Poor's ExecuComp Data, 1992-2003 with partial year data through Q3 for 2003. 
TABLE 3. SALARY AND COMPENSATION FOR MEN AND WOMEN EXECUTIVES, 1992-2003¹

\begin{tabular}{|l|l|l|l|c|}
\hline & Women & Men & Difference & $\begin{array}{c}\text { Ratio of } \\
\text { Female to } \\
\text { Male Pay }\end{array}$ \\
\hline \hline $\begin{array}{l}\text { Real Gross Compensation, } \\
\text { Thousands of 1992 Dollars }\end{array}$ & $1,186.560$ & $1,648.966$ & $\$ 462.406^{* \star *}$ & .720 \\
\hline $\begin{array}{l}\text { Real Cash Compensation, } \\
\text { Thousands of 1992 Dollars }\end{array}$ & 372.146 & 525.761 & $\$ 153.615^{* \star \star}$ & .708 \\
\hline $\begin{array}{l}\text { Real Salary, Thousands of } \\
\text { 1992 Dollars }\end{array}$ & 221.086 & 282.816 & $\$ 61.730^{* \star *}$ & .782 \\
\hline \hline
\end{tabular}

${ }^{1}$ Source: Standard and Poor's ExecuComp Data, 1992-2003 with partial year data through Q3 for 2003.

${ }^{2}$ Real gross compensation is equal to the sum of salary, executive bonus, other annual incentive pay, long-term incentive pay, the Black-Scholes value of potions granted, and the value of restricted options.

${ }^{3}$ Cash Compensation includes salary plus executive bonus.

${ }^{* * *}$ Implies statistical significance at greater than the 99\% confidence level. 
TABLE 4. GENDER PAY GAP FOR WOMEN EXECUTIVES ${ }^{1}$ (White-Corrected Standard Errors in Parentheses)

Dependent Variable: Log of Real Salary, Total Cash Compensation, Gross Compensation, 1992-2003 ${ }^{2}$

\begin{tabular}{|c|c|c|c|c|c|c|c|c|}
\hline Independent Variables & $\begin{array}{c}1 . \\
\text { Comp. }^{2}\end{array}$ & $\begin{array}{c}2 . \\
\text { Comp. }^{2}\end{array}$ & $\begin{array}{c}3 . \\
\text { Comp. }^{2}\end{array}$ & $\begin{array}{c}4 . \\
\text { Comp. }\end{array}$ & $\begin{array}{c}5 . \\
\text { Salary }\end{array}$ & $\begin{array}{c}6 . \\
\text { Salary }\end{array}$ & $\begin{array}{c}7 . \\
\text { Cash- } \\
\text { Comp. } \\
\end{array}$ & $\begin{array}{c}8 . \\
\text { Cash- } \\
\text { Comp. }^{3} \\
\end{array}$ \\
\hline Female & $\begin{array}{l}-.254^{\star \star \star} \\
(.016)\end{array}$ & $\begin{array}{l}-.108^{\star \star \star} \\
(.013)\end{array}$ & $\begin{array}{l}-.078^{\star \star \star} \\
(.012)\end{array}$ & $\begin{array}{l}-.111^{* \star *} \\
(.032)\end{array}$ & $\begin{array}{l}-.119^{\star \star \star} \\
(.007)\end{array}$ & $\begin{array}{l}-.100^{\star * *} \\
(.007)\end{array}$ & $\begin{array}{l}-.137^{\star \star \star} \\
(.008)\end{array}$ & $\begin{array}{l}-.111^{\star \star \star} \\
(.008)\end{array}$ \\
\hline Log (Market Valuation) & & $\begin{array}{l}.338^{\star * \star} \\
(.003)\end{array}$ & $\begin{array}{l}.328^{\star * \star} \\
(.003)\end{array}$ & $\begin{array}{l}.362^{* \star \star} \\
(.005)\end{array}$ & $\begin{array}{l}.085^{k * *} \\
(.002)\end{array}$ & $\begin{array}{l}.078^{\star \star \star} \\
(.001)\end{array}$ & $\begin{array}{l}.169^{\star \star \star *} \\
(.002)\end{array}$ & $\begin{array}{l}.161^{\star \star *} \\
(.002)\end{array}$ \\
\hline Log (Employment) & & $\begin{array}{l}.063^{\star * *} \\
(.003)\end{array}$ & $\begin{array}{l}.045^{\star * \star} \\
(.003)\end{array}$ & $\begin{array}{l}.059^{\text {*** }} \\
(.005)\end{array}$ & $\begin{array}{l}.120^{* * *} \\
(.002)\end{array}$ & $\begin{array}{l}.108^{\star \star *} \\
(.002)\end{array}$ & $\begin{array}{l}.123^{\star \star \star} \\
(.002)\end{array}$ & $\begin{array}{l}.109^{\star * *} \\
(.002)\end{array}$ \\
\hline Year Controls & & Yes & Yes & Yes & Yes & Yes & Yes & Yes \\
\hline Industry Controls & & Yes & Yes & Yes & Yes & Yes & Yes & Yes \\
\hline Detail Occupation Controls & & & Yes & & & Yes & & Yes \\
\hline Pay Rank Controls & & Yes & & Yes & Yes & & Yes & \\
\hline CEO/Chair Controls & & Yes & & Yes & Yes & & Yes & \\
\hline Age & & & & $\begin{array}{c}.048 \\
(.005)\end{array}$ & & & & \\
\hline Age-Squared & & & & $\begin{array}{l}-.0005 \\
(.0000)\end{array}$ & & & & \\
\hline $\mathrm{R}^{2}$ & .002 & .477 & .489 & .429 & .362 & .380 & .465 & .479 \\
\hline N & 108,509 & 104,445 & 104,445 & 40,003 & 122,766 & 122,766 & 122,868 & 122,868 \\
\hline
\end{tabular}

"Source: Standard and Poor's "ExecuComp" Data, 1992-2003, with partial year data through Q3 for 2003. ${ }^{2}$ Total gross compensation is equal to the sum of salary, executive bonus, other annual incentive pay, long-term incentive pay, the Black-Scholes value of options granted, and the value of restricted options. ${ }^{3}$ Cash compensation is equal to salary plus executive bonus.

* Implies statistical significance at greater than the 90\% confidence level, ${ }^{* *} 95 \%$ confidence level, and ${ }^{* *} 99 \%$ confidence level respectively. 
TABLE 5. EDUCATIONAL BACKGROUND OF EXECUCOMP TECHNOLOGY EXECUTIVES ${ }^{1}$

\begin{tabular}{|l|c|c|}
\hline & $\begin{array}{c}\text { Men } \\
(n=3054)\end{array}$ & $\begin{array}{c}\text { Women } \\
(n=296)\end{array}$ \\
\hline Percent with Terminal Undergraduate Degree & $\begin{array}{c}42.1 \\
(0.90)\end{array}$ & $\begin{array}{c}40.6 \\
(2.90)\end{array}$ \\
\hline Percent with Degree from Private College & 50.2 & 52.9 \\
& $(0.93)$ & $(3.00)$ \\
\hline Percent with Degree from Top University & 19.3 & 19.9 \\
& $(0.73)$ & $(2.25)$ \\
\hline Percent with MBA & 34.6 & 29.1 \\
& $(0.86)$ & $(2.64)$ \\
\hline Percent with PhD & $(0.49)$ & 5.7 \\
& & $(1.35)$ \\
\hline Percent with JD & $(0.50)$ & 14.9 \\
& & $(2.07)$ \\
\hline
\end{tabular}

${ }^{1}$ Sample: Technology Executives from ExecuComp, 1992-2001.

${ }^{2}$ Top University is Defined as a Top-20 University or a Top-20 Liberal Arts College from US News and World Reports College Rankings, 2005. 
TABLE 6. SALARY DIFFERENCES BY GENDER OF COMPANY HEAD (LESS-RESTRICTIVE) ${ }^{1}$

\begin{tabular}{|c|c|c|c|c|}
\hline & & $\begin{array}{l}\text { Firm with Female } \\
\text { CEOI Chair }\end{array}$ & Other Firms ${ }^{2}$ & Difference \\
\hline 1 & Real Salary, All Women Executives & 329.711 & 203.018 & $126.693^{* \star *}$ \\
\hline 2 & Real Salary, All Male Executives & 313.908 & 281.798 & $32.11^{\star \star * *}$ \\
\hline 3 & Difference & $15.803^{* * *}$ & $-78.780^{* * *}$ & $\mathbf{x}$ \\
\hline 4 & $\begin{array}{l}\text { Real Salary, Women Executives } \\
\text { Excluding CEO/Chair }\end{array}$ & 229.159 & 203.018 & $26.141^{* * *}$ \\
\hline 5 & $\begin{array}{l}\text { Real Salary, Male Executives } \\
\text { Excluding CEO/Chair }\end{array}$ & 251.823 & 230.026 & $21.797^{\star * *}$ \\
\hline 6 & Difference & $-22.664^{\star \star *}$ & $-27.008^{* * *}$ & $x$ \\
\hline 7 & $\begin{array}{l}\text { Real Cash Compensation }{ }^{3} \text {, Women } \\
\text { Executives Excluding CEO/Chair }\end{array}$ & 376.275 & 339.285 & $36.990^{* * *}$ \\
\hline 8 & $\begin{array}{l}\text { Real Cash Compensation }{ }^{3} \text {, Male } \\
\text { Executives Excluding CEO/Chair }\end{array}$ & 430.163 & 405.177 & $24.986^{* * *}$ \\
\hline 9 & Difference & $-53.888^{\star \star \star}$ & $-65.892^{\star \star \star}$ & $\mathbf{x}$ \\
\hline 10 & $\begin{array}{l}\text { Real Gross Compensation }{ }^{4} \text {, Women } \\
\text { Executives Excluding CEO/Chair }\end{array}$ & $1,261.901$ & 969.737 & $292.164^{* *}$ \\
\hline 11 & $\begin{array}{l}\text { Real Gross Compensation }{ }^{4} \text {, Male } \\
\text { Executives Excluding CEO/Chair }\end{array}$ & $1,298.602$ & $1,126.305$ & $172.297^{\star \star \star}$ \\
\hline 12 & Difference & 36.701 & $-156.568^{\star *}$ & $x$ \\
\hline
\end{tabular}

${ }^{1}$ Source: Standard and Poor's ExecuComp Data, 1997-2003 with data through Q3 for 2003.

${ }^{2}$ Firms with a Chair, CEO, Chair/CEO who is female; other firms are firms that do not have a female Chair, CEO, or Chair/CEO. ${ }^{3}$ Cash Compensation includes salary plus executive bonus. ${ }^{4}$ Real gross compensation is equal to the sum of salary, executive bonus, other annual incentive pay, long-term incentive pay, the Black-Scholes value of options granted, and the value of restricted options. ${ }^{\text {t*k }}$ All differences statistically significant at greater than the $99 \%$ level. 
TABLE 7. SALARY DIFFERENCES BY GENDER OF COMPANY HEAD (MORE-RESTRICTIVE) ${ }^{1}$

\begin{tabular}{|c|c|c|c|c|}
\hline & & $\begin{array}{c}\text { Firm with Female } \\
\text { CEO/Chair \& } \\
\text { Director }^{2}\end{array}$ & Other Firms ${ }^{2}$ & Difference \\
\hline 1 & Real Salary, All Women Executives & 336.663 & 205.554 & $131.109^{* \star *}$ \\
\hline 2 & Real Salary, All Male Executives & 263.803 & 283.206 & -19.403 \\
\hline 3 & Difference & $72.860^{* \star *}$ & $-77.652^{* * *}$ & $\mathbf{x}$ \\
\hline 4 & $\begin{array}{l}\text { Real Salary, Women Executives } \\
\text { Excluding CEO/Chair }\end{array}$ & 218.837 & 203.878 & $14.959^{* *}$ \\
\hline 5 & $\begin{array}{l}\text { Real Salary, Male Executives } \\
\text { Excluding CEO/Chair }\end{array}$ & 226.448 & 230.806 & -4.358 \\
\hline 6 & Difference & -7.611 & $-26.928^{* * *}$ & $\mathrm{X}$ \\
\hline 7 & $\begin{array}{l}\text { Real Cash Compensation }{ }^{3} \text {, Women } \\
\text { Executives Excluding CEO/Chair }\end{array}$ & 329.436 & 342.490 & $-13.054^{* \star *}$ \\
\hline 8 & $\begin{array}{l}\text { Real Cash Compensation }{ }^{3} \text {, Male } \\
\text { Executives Excluding CEO/Chair }\end{array}$ & 348.337 & 407.275 & $-58.938^{\star \star *}$ \\
\hline 9 & Difference & -18.901 & $-26.930^{\star \star \star}$ & $\mathbf{x}$ \\
\hline 10 & $\begin{array}{l}\text { Real Gross Compensation }{ }^{4} \text {, Women } \\
\text { Executives Excluding CEO/Chair }\end{array}$ & $1,167.368$ & 977.728 & $189.640^{* *}$ \\
\hline 11 & $\begin{array}{l}\text { Real Gross Compensation }{ }^{4} \text {, Male } \\
\text { Executives Excluding CEO/Chair }\end{array}$ & $1,082.184$ & $1,132.707$ & -50.523 \\
\hline 12 & Difference & 85.184 & $-154.979^{* *}$ & $\mathrm{X}$ \\
\hline
\end{tabular}

${ }^{1}$ Source: Standard and Poor's ExecuComp Data, 1997-2003 with data through Q3 for $2003 .{ }^{2}$ Firms with a Chair, CEO, Chair/CEO who is female and a member of the Board of Directors; All other Firms. ${ }^{3}$ Cash Compensation includes salary plus executive bonus. ${ }^{4}$ Real gross compensation is equal to the sum of salary, executive bonus, other annual incentive pay, long-term incentive pay, the Black-Scholes value of options granted, and the value of restricted options.

${ }^{* * *}$ All differences statistically significant at greater than the $99 \%$ level. 
TABLE 8. GENDER REPRESENTATION BY GENDER OF COMPANY HEAD ${ }^{1}$

\begin{tabular}{|l||c|c||c|c|}
\hline \multicolumn{1}{|c||}{} & $\begin{array}{c}\text { Firm with Female } \\
\text { CEO/Chair }\end{array}$ & Other Firms ${ }^{2}$ & Difference \\
\hline 1 & $\begin{array}{c}\text { Percent of Executives That Are } \\
\text { Female }\end{array}$ & 17.304 & 3.957 & $13.347^{+*+*}$ \\
\hline 2 & $\begin{array}{c}\text { Percent of Executives That Are } \\
\text { Female Excluding CEO/Chair }\end{array}$ & 11.002 & 5.340 & $\mathbf{5 . 6 6 2}$ \\
\hline & $\begin{array}{c}\text { Firm with Female } \\
\text { CEO/Chair \& } \\
\text { Director }\end{array}$ & Other Firms ${ }^{2}$ & \\
\hline 3 & $\begin{array}{c}\text { Percent of Executives That Are } \\
\text { Female }\end{array}$ & 21.499 & 4.017 & $\mathbf{1 7 . 4 8 2}$ \\
\hline 4 & $\begin{array}{c}\text { Percent of Executives That Are } \\
\text { Female Excluding CEO/Chair }\end{array}$ & 13.226 & 5.337 & $\mathbf{7 . 8 8 9}$ \\
\hline
\end{tabular}

${ }^{1}$ Source: Standard and Poor's ExecuComp Data, 1997-2003 with data through Q3 for 2003 and IRRC Directors Data Set for Director data.

${ }^{2}$ Firms with a Chair, CEO, Chair/CEO who is female; other firms are firms that do not have a female Chair, CEO, or Chair/CEO..

${ }^{* * *}$ Differences statistically significant at greater than the 99\% confidence level. 
TABLE 9. GENDER PAY GAP FOR WOMEN EXECUTIVES IN WOMEN-LED COMPANIES ${ }^{1}$ (White-Corrected Standard Errors in Parentheses)

\begin{tabular}{|c|c|c|c|c|c|c|c|c|c|c|}
\hline & Femal & -Led is $\mathrm{C}$ & $\begin{array}{l}\text { mpany w } \\
\text { r, Chair/c }\end{array}$ & $\begin{array}{l}\text { th Female } \\
\text { EO }\end{array}$ & CEO, & Femal & $\begin{array}{l}\text {-Led is C } \\
\text { hair, Cha }\end{array}$ & $\begin{array}{l}\text { mpany n } \\
\text { /CEO an }\end{array}$ & $\begin{array}{l}\text { th Female } \\
\text { a Directc }\end{array}$ & CEO, \\
\hline $\begin{array}{c}\text { Independent } \\
\text { Variables }\end{array}$ & $\begin{array}{l}1 . \\
\text { All }\end{array}$ & $\begin{array}{l}2 . \\
\text { All }\end{array}$ & $\begin{array}{l}\text { All } \\
\text { All }\end{array}$ & $\begin{array}{c}4 . \\
\text { No CEOs } \\
\text { Chairs }\end{array}$ & $\begin{array}{l}5 . \\
\text { All }\end{array}$ & $\begin{array}{l}6 . \\
\text { All }\end{array}$ & $\begin{array}{l}\text { Aill } \\
\text { Al }\end{array}$ & $\begin{array}{l}8 . \\
\text { All }\end{array}$ & $\begin{array}{c}9 . \\
\text { No CEOs } \\
\text { Chairs }\end{array}$ & $\begin{array}{l}10 . \\
\text { All }\end{array}$ \\
\hline Female & $\begin{array}{l}-.341^{* \star *} \\
(, 017)\end{array}$ & $\begin{array}{c}-.129^{\star \star \star} \\
(.013) \\
\end{array}$ & $\begin{array}{l}-.082^{* \star \star} \\
(.013)\end{array}$ & $\begin{array}{l}-.129^{\star \star \star} \\
(.013)\end{array}$ & $\begin{array}{l}-.198^{\star \star \star} \\
(.039)\end{array}$ & $\begin{array}{l}-.330^{* * *} \\
(.017)\end{array}$ & $\begin{array}{l}-.142^{\star \star \star} \\
(.013)\end{array}$ & $\begin{array}{l}-.093^{* * *} \\
(.013)\end{array}$ & $\begin{array}{c}-.129^{\star \star \star} \\
(.013) \\
\end{array}$ & $\begin{array}{l}-.180^{\star * \star} \\
(.038)\end{array}$ \\
\hline $\begin{array}{l}\text { Fem-Led } \\
\text { Company }\end{array}$ & $\begin{array}{l}-.004 \\
(.014)\end{array}$ & $\begin{array}{l}-.016 \\
(.015)\end{array}$ & $\begin{array}{l}-.004 \\
(.014)\end{array}$ & $\begin{array}{l}-.001 \\
(.016)\end{array}$ & $\begin{array}{l}.005 \\
(.025)\end{array}$ & $\begin{array}{l}-.148^{\star \star \star} \\
(.024)\end{array}$ & $\begin{array}{l}-.039^{* *} \\
(.018)\end{array}$ & $\begin{array}{l}-.021 \\
(.018)\end{array}$ & $\begin{array}{l}-.035^{*} \\
(.019)\end{array}$ & $\begin{array}{l}-.062^{*} \\
(.032)\end{array}$ \\
\hline $\begin{array}{l}\text { Female in Fem- } \\
\text { Led Company }\end{array}$ & $\begin{array}{l}.465^{* * *} \\
(.052)\end{array}$ & $\begin{array}{l}.080^{* *} \\
(.039)\end{array}$ & $\begin{array}{l}.025 \\
(.038)\end{array}$ & $\begin{array}{l}.085^{*} \\
(.047)\end{array}$ & $\begin{array}{l}.192^{* *} \\
(.070)\end{array}$ & $\begin{array}{l}.708^{\star \star \star} \\
(.057)\end{array}$ & $\begin{array}{l}.203^{* * *} \\
(.043)\end{array}$ & $\begin{array}{l}.126^{\star * \star} \\
(.042)\end{array}$ & $\begin{array}{l}.108^{* *} \\
(.049)\end{array}$ & $\begin{array}{l}.270^{* * *} \\
(.074)\end{array}$ \\
\hline $\begin{array}{c}\text { Log } \\
\text { (Market Value) }\end{array}$ & & $\begin{array}{l}.336^{* * \star} \\
(.003)\end{array}$ & $\begin{array}{l}.329^{* * \star} \\
(.003)\end{array}$ & $\begin{array}{l}.338^{\star \star \star} \\
(.003)\end{array}$ & $\begin{array}{l}.359^{* \star *} \\
(.005)\end{array}$ & & $\begin{array}{l}.336^{* * *} \\
(.003)\end{array}$ & $\begin{array}{l}.328^{* * *} \\
(.003)\end{array}$ & $\begin{array}{l}.338^{\star \star \star} \\
(.003)\end{array}$ & $\begin{array}{l}.362^{\star \star \star} \\
(.005)\end{array}$ \\
\hline Log (Employ) & & $\begin{array}{l}.059^{\star * \star} \\
(.003)\end{array}$ & $\begin{array}{l}.045^{* * *} \\
(.003)\end{array}$ & $\begin{array}{l}.052^{* * *} \\
(.003)\end{array}$ & $\begin{array}{l}.061^{* * *} \\
(.005)\end{array}$ & . & $\begin{array}{l}.058^{* * *} \\
(.003)\end{array}$ & $\begin{array}{l}.045^{* * *} \\
(.003)\end{array}$ & $\begin{array}{l}.052^{\star * *} \\
(.003)\end{array}$ & $\begin{array}{l}.059^{* * *} \\
(.005)\end{array}$ \\
\hline Year & & Yes & Yes & Yes & Yes & & Yes & Yes & Yes & Yes \\
\hline Industry & & Yes & Yes & Yes & Yes & & Yes & Yes & Yes & Yes \\
\hline CEO/Chair & & Yes & & & Yes & & Yes & & & Yes \\
\hline $\begin{array}{c}\text { Detail } \\
\text { Occupation }\end{array}$ & & & Yes & & & & & Yes & & \\
\hline Age & & & & & $\begin{array}{l}.053^{* \star \star} \\
(.005)\end{array}$ & & & & & $\begin{array}{l}.047^{\star \star \star} \\
(.005)\end{array}$ \\
\hline $\mathrm{Age}^{2}$ & & & & & $\begin{array}{l}-.001^{\star \star \star} \\
(.000)\end{array}$ & & & & & $\begin{array}{c}-.0004^{*+*+} \\
(.000)\end{array}$ \\
\hline $\mathrm{R}^{2}$ & .004 & .441 & .489 & .446 & .418 & .005 & .465 & .489 & .446 & .429 \\
\hline$N$ & 108,509 & 104,445 & 104,445 & 74,259 & 40,003 & 108,509 & 104,445 & 104,445 & 74,259 & 40,003 \\
\hline
\end{tabular}

${ }^{1}$ Source: Standard and Poor's "ExecuComp" Data, 1992-2003, with partial year data through Q3 for 2003. ${ }^{2}$ Total gross compensation is equal to the sum of salary, executive bonus, other annual incentive pay, long-term incentive pay, the Black-Scholes value of options granted, and the value of restricted options. * Implies statistical significance at greater than the $90 \%$ confidence level, ${ }^{*} 95 \%$ confidence level, and ${ }^{* \star *} 99 \%$ confidence level respectively. 
TABLE 10. FEMALE-HEADED FIRMS AND PROBABILITY OF WOMEN-EXECUTIVES, 1992-2003 ${ }^{1}$

Dependent Variable: $=1$ if Woman Executive, =0 if Male Executive, 1992-2003

\begin{tabular}{|c|c|c|c|c|c|c|c|c|}
\hline & \multicolumn{4}{|c|}{$\begin{array}{l}\text { Female-Led is Company with Female } \\
\text { CEO, Chair or Chair/CEO }\end{array}$} & \multicolumn{4}{|c|}{$\begin{array}{l}\text { Female-Led is Company with Female } \\
\text { CEO, Chair, Chair/CEO, and Director }\end{array}$} \\
\hline Independent Variables & $\begin{array}{l}1 . \\
\text { All }\end{array}$ & $\begin{array}{l}2 . \\
\text { All }\end{array}$ & $\begin{array}{c}3 . \\
\times \text { CEO/ } \\
\text { Chair }^{2} \\
\end{array}$ & $\begin{array}{c}4 . \\
\times \text { CEO/ } \\
\text { Chair }^{2} \\
\end{array}$ & $\begin{array}{l}5 . \\
\text { All }\end{array}$ & $\begin{array}{l}6 . \\
\text { All }\end{array}$ & $\begin{array}{c}7 . \\
\times \text { CEO/ } \\
\text { Chair }^{2} \\
\end{array}$ & $\begin{array}{c}8 . \\
\times \text { CEO/ } \\
\text { Chair }^{2} \\
\end{array}$ \\
\hline $\begin{array}{l}\text { Fem-Led Company } \\
\text { Dummy }\end{array}$ & $\begin{array}{l}.133^{\star * *} \\
(.006)\end{array}$ & $\begin{array}{l}.113^{\text {*** }} \\
(.006)\end{array}$ & $\begin{array}{l}.057^{\star \star \star} \\
(.006)\end{array}$ & $\begin{array}{l}.033^{\star \star *} \\
(.005)\end{array}$ & $\begin{array}{l}.175^{\star * \star} \\
(.007)\end{array}$ & $\begin{array}{l}.128^{\star \star *} \\
(.007)\end{array}$ & $\begin{array}{l}.079^{* * *} \\
(.007)\end{array}$ & $\begin{array}{l}.042^{\text {*** }} \\
(.006)\end{array}$ \\
\hline Log (Market Valuation) & & $\begin{array}{c}.001^{* *} \\
(.0004)\end{array}$ & & $\begin{array}{c}.001^{*} \\
(.0006)\end{array}$ & & $\begin{array}{c}.001^{* *} \\
(.0004)\end{array}$ & & $\begin{array}{c}.001^{*} \\
(.0006)\end{array}$ \\
\hline Log (Employment) & & $\begin{array}{l}-.003^{\star \star \star} \\
(.0004)\end{array}$ & & $\begin{array}{l}-.005^{\star \star \star} \\
(.0007)\end{array}$ & & $\begin{array}{l}-.003^{\star \star \star} \\
(.0004)\end{array}$ & & $\begin{array}{l}-.005^{* \star *} \\
(.0007)\end{array}$ \\
\hline Year Controls & & Yes & & Yes & & Yes & & Yes \\
\hline Industry Controls & & Yes & & Yes & & Yes & & Yes \\
\hline Detail Occupation Controls & & Yes & & Yes & & Yes & & Yes \\
\hline $\log L(x 1000)$ & $-22,798$ & $-19,659$ & $-20,216$ & $-18,028$ & $-22,770$ & $-19,728$ & $-20,191$ & -18.021 \\
\hline $\mathrm{N}$ & 128,570 & 122,744 & 94,905 & 90,603 & 128,570 & 122,744 & 94,905 & 90,603 \\
\hline$\%$ Positive N & 4.445 & 4.420 & 5.529 & 5.493 & 4.445 & 4.420 & 5.529 & 5.493 \\
\hline
\end{tabular}

${ }^{1}$ Source: Standard and Poor's "ExecuComp" Data, 1992-2003, with partial year data through Q3 for 2003.

${ }^{2}$ Probit regressions exclude all executives with CEO, Chair or Chair and CEO title.

* Implies statistical significance at greater than the $90 \%$ confidence level, ${ }^{* *} 95 \%$ confidence level, and ${ }^{* *} 99 \%$ confidence level respectively. 
TABLE 11. COMPENSATION AND GENDER REPRESENTATION BY BOARD COMPOSITION $^{1}$

\begin{tabular}{|c|c|c|c|}
\hline \multicolumn{4}{|c|}{ PANEL A. COMPENSATION DIFFERENCES } \\
\hline & $\begin{array}{l}\text { High-Share of } \\
\text { Female Directors }\end{array}$ & $\begin{array}{l}\text { No Female } \\
\text { Directors }\end{array}$ & Difference \\
\hline $\begin{array}{l}\text { Real Compensation, } \\
\text { All Women Executives }\end{array}$ & $1,881.049$ & $1,045.057$ & $835.992^{\star * *}$ \\
\hline $\begin{array}{l}\text { Real Compensation, } \\
\text { All Male Executives }\end{array}$ & $2,735.228$ & $1,759.492$ & $975.736^{\star \star *}$ \\
\hline Difference & $-854.179^{\star \star \star *}$ & $-714.435^{\star \star \star}$ & $\mathbf{x}$ \\
\hline \multicolumn{4}{|c|}{ PANEL B. GENDER REPRESENTATION DIFFERENCES } \\
\hline & $\begin{array}{l}\text { High-Share of } \\
\text { Female Directors }\end{array}$ & $\begin{array}{l}\text { No Female } \\
\text { Directors }^{2}\end{array}$ & Difference \\
\hline $\begin{array}{l}\text { Percent of Executives } \\
\text { That Are Female }\end{array}$ & 8.288 & 3.812 & $4.476^{* * *}$ \\
\hline
\end{tabular}

\footnotetext{
${ }^{1}$ Source: IRRC Directors Data, 1997-2001 and ExecuComp Data, 1997-2001.

${ }^{2}$ The no female directors implies bottom-quartile of data on female Board representation. High share of female directors implies top-quartile of data and greater than or equal to $13.33 \%$ of female directors.

${ }^{* \star *}$ Implies statistically significant differences at greater than 99\% confidence level.
} 
TABLE 12. THE GENDER PAY GAP IN FEMALE-LED COMPANIES WITH INFORMATION ON DIRECTORS ${ }^{1}$, 1997-2001

(White-Corrected Standard Errors in Parentheses)

Dependent Variable: Log of Gross Compensation, 1997-2001²

\begin{tabular}{|c|c|c|c|c|c|c|c|c|c|}
\hline & \multicolumn{5}{|c|}{$\begin{array}{c}\text { Female-Led is Company with Female CEO, Chair or } \\
\text { Chair/CEO }\end{array}$} & \multicolumn{4}{|c|}{$\begin{array}{l}\text { Female-Led is Company with Female CEO, } \\
\text { Chair or Chair/CEO, who is also a Director }\end{array}$} \\
\hline & 1. & 2. & 3. & 4. & 5. & 6. & 7. & 8. & 9. \\
\hline Female & $\begin{array}{l}-.374^{* \star *} \\
(.041)\end{array}$ & $\begin{array}{l}-.380^{* \star *} \\
(.034)\end{array}$ & $\begin{array}{l}-.171^{* * *} \\
(.034)\end{array}$ & $\begin{array}{l}-.086^{\star \star *} \\
(.033)\end{array}$ & $\begin{array}{l}-.105^{* \star *} \\
(.034)\end{array}$ & $\begin{array}{l}-.372^{* * \star} \\
(.034)\end{array}$ & $\begin{array}{l}-.170^{\star \star *} \\
(.034)\end{array}$ & $\begin{array}{l}-.086^{* * *} \\
(.033)\end{array}$ & $\begin{array}{l}-.105^{* \star *} \\
(.033)\end{array}$ \\
\hline $\begin{array}{l}\text { Fem-Led Company } \\
\text { Dummy }\end{array}$ & $\begin{array}{l}-.163^{* *} \\
(.041)\end{array}$ & $\begin{array}{l}-.037 \\
(.030)\end{array}$ & $\begin{array}{l}-.057^{*} \\
(.028)\end{array}$ & $\begin{array}{l}-.047 \\
(.027)\end{array}$ & $\begin{array}{l}-.038 \\
(.029)\end{array}$ & $\begin{array}{l}-.144^{* \star *} \\
(.035)\end{array}$ & $\begin{array}{l}-.112^{* * *} \\
(.033)\end{array}$ & $\begin{array}{l}-.101^{* \star \star} \\
(.031)\end{array}$ & $\begin{array}{l}-.106^{* \star \star} \\
(.034)\end{array}$ \\
\hline $\begin{array}{l}\text { Female-Led } \\
\text { Company * Fem }\end{array}$ & $\begin{array}{l}.512^{\star \star *} \\
(.101)\end{array}$ & $\begin{array}{l}.574^{\star \star \star} \\
(.079)\end{array}$ & $\begin{array}{l}.035 \\
(.075)\end{array}$ & $\begin{array}{r}-.005 \\
(.074)\end{array}$ & $\begin{array}{l}.106 \\
(.082)\end{array}$ & $\begin{array}{l}.604^{* \star \star} \\
(.088)\end{array}$ & $\begin{array}{l}.155^{*} \\
(.082)\end{array}$ & $\begin{array}{l}.091 \\
(.080)\end{array}$ & $\begin{array}{l}.136^{* *} \\
(.086)\end{array}$ \\
\hline $\begin{array}{l}\text { Share Female } \\
\text { Directors }\end{array}$ & $\begin{array}{c}2.222^{\star \star \star} \\
(.083)\end{array}$ & $\begin{array}{l}.366^{\star \star \star} \\
(.074)\end{array}$ & $\begin{array}{l}.361^{\star \star \star} \\
(.067)\end{array}$ & $\begin{array}{l}346^{\star \star *} \\
(.066)\end{array}$ & $\begin{array}{l}.329^{\star \star \star} \\
(.067)\end{array}$ & $\begin{array}{l}.404^{* * *} \\
(.073)\end{array}$ & $\begin{array}{l}.378^{\star \star \star} \\
(.067)\end{array}$ & $\begin{array}{l}.365^{* \star \star} \\
(.066)\end{array}$ & $\begin{array}{l}.358^{\star \star \star} \\
(.067)\end{array}$ \\
\hline $\begin{array}{l}\text { Share Female } \\
\text { Directors * Fem }\end{array}$ & $\begin{array}{l}-.296 \\
(.285)\end{array}$ & $\begin{array}{l}.562^{\star *} \\
(.229)\end{array}$ & $\begin{array}{l}.641^{\star \star \star} \\
(.226)\end{array}$ & $\begin{array}{l}.256 \\
(.220)\end{array}$ & $\begin{array}{l}.450^{* *} \\
(.228)\end{array}$ & $\begin{array}{l}.534^{\star \star \star} \\
(.231)\end{array}$ & $\begin{array}{l}.542^{\star *} \\
(.229)\end{array}$ & $\begin{array}{l}.183 \\
(.221)\end{array}$ & $\begin{array}{l}.454^{* *} \\
(.229)\end{array}$ \\
\hline $\begin{array}{l}\text { Additional Controls } \\
\text { Added }\end{array}$ & No & $\begin{array}{l}\text { Ln Market } \\
\text { Value, Ln } \\
\text { Employ, } \\
\text { Year, SIC2 }\end{array}$ & $\begin{array}{c}\text { Column (2) } \\
\text { Plus } \\
\text { CEO/Chair }\end{array}$ & $\begin{array}{c}\text { Column (2) } \\
\text { Plus } \\
\text { Detailed } \\
\text { Occupation }\end{array}$ & $\begin{array}{l}\text { Column (2) } \\
\text { Plus } \\
\text { Detailed } \\
\text { Occupation } \\
\text { Excluding } \\
\text { CEO/Chair }\end{array}$ & $\begin{array}{l}\text { Ln Market } \\
\text { Value, Ln } \\
\text { Employ, } \\
\text { Year, SIC2 }\end{array}$ & $\begin{array}{l}\text { Column (6) } \\
\text { Plus } \\
\text { CEO/Chair }\end{array}$ & $\begin{array}{c}\text { Column (6) } \\
\text { Plus } \\
\text { Detailed } \\
\text { Occupation }\end{array}$ & $\begin{array}{l}\text { Column (6) } \\
\text { Plus } \\
\text { Detailed } \\
\text { Occupation } \\
\text { Excluding } \\
\text { CEO/Chair }\end{array}$ \\
\hline $\mathrm{R}^{2}$ & .027 & .382 & .466 & .491 & .489 & .382 & .466 & .491 & .489 \\
\hline $\mathrm{N}$ & 32,335 & 31,711 & 31,711 & 31,711 & 22,700 & 31,711 & 31,711 & 31,711 & 22,700 \\
\hline
\end{tabular}

${ }^{1}$ Sources: Standard and Poor's “ExecuComp” Data, 1997-2001, IRRC Directors Data, 1997-2001.

${ }^{2}$ Total gross compensation is equal to the sum of salary, executive bonus, other annual incentive pay, longterm incentive pay, the Black-Scholes value of options granted, and the value of restricted options.

* Implies statistical significance at greater than the 90\% confidence level, ${ }^{* *} 95 \%$ confidence level, and ${ }^{\star \star *} 99 \%$ confidence level respectively. 
TABLE 13. FIXED EFFECTS ESTIMATES OF THE GENDER PAY GAP IN FEMALE-LED COMPANIES, 1997-2001 ${ }^{1}$

Dependent Variable: Log of Gross Compensation, 1997-2001²

\begin{tabular}{|c|c|c|c|c|c|c|c|c|}
\hline & \multicolumn{4}{|c|}{$\begin{array}{l}\text { Female-Led is Company with Female CEO, } \\
\text { Chair or Chair/CEO }\end{array}$} & \multicolumn{4}{|c|}{$\begin{array}{l}\text { Female-Led is Company with Female CEO, } \\
\text { Chair or Chair/CEO, who is also a Director }\end{array}$} \\
\hline & $\begin{array}{c}1 . \\
\text { Company } \\
\text { FE } \\
\end{array}$ & $\begin{array}{c}2 . \\
\text { Company } \\
\text { FE } \\
\end{array}$ & $\begin{array}{c}3 . \\
\text { Individual } \\
\mathrm{FE} \\
\end{array}$ & $\begin{array}{c}4 . \\
\text { Individual } \\
\text { FE } \\
\end{array}$ & $\begin{array}{c}5 . \\
\text { Company } \\
\text { FE } \\
\end{array}$ & $\begin{array}{c}6 . \\
\text { Company } \\
\text { FE } \\
\end{array}$ & $\begin{array}{c}7 . \\
\text { Individual } \\
\text { FE } \\
\end{array}$ & $\begin{array}{c}8 . \\
\text { Individual } \\
\mathrm{FE} \\
\end{array}$ \\
\hline Female & $\begin{array}{l}-.126^{\star \star \star} \\
(.022)\end{array}$ & $\begin{array}{l}-.114^{* \star \star} \\
(.019)\end{array}$ & $\begin{array}{l}-.171^{\star \star \star} \\
(.034)\end{array}$ & $\begin{array}{l}-.086^{\star \star *} \\
(.033)\end{array}$ & $\begin{array}{l}-.149^{* * \star} \\
(.022)\end{array}$ & $\begin{array}{l}-.114^{\star \star \star} \\
(.019)\end{array}$ & $\begin{array}{l}-.086^{* * \star} \\
(.033)\end{array}$ & $\begin{array}{l}-.105^{\star \star \star} \\
(.033)\end{array}$ \\
\hline $\begin{array}{l}\text { Fem-Led Company } \\
\text { Dummy }\end{array}$ & NA & NA & $\begin{array}{l}-.057^{\star \star} \\
(.028)\end{array}$ & $\begin{array}{r}-.047 \\
(.027)\end{array}$ & NA & NA & $\begin{array}{l}-.101^{\star \star \star} \\
(.031)\end{array}$ & $\begin{array}{l}-.106^{\star \star \star} \\
(.034)\end{array}$ \\
\hline $\begin{array}{l}\text { Female-Led } \\
\text { Company * Fem }\end{array}$ & $\begin{array}{l}.048 \\
(.056)\end{array}$ & $\begin{array}{l}.152^{* *} \\
(.072)\end{array}$ & $\begin{array}{l}.035 \\
(.075)\end{array}$ & $\begin{array}{r}-.005 \\
(.074)\end{array}$ & $\begin{array}{l}.183^{\star \star \star} \\
(.063)\end{array}$ & $\begin{array}{l}.173^{* \star} \\
(.077)\end{array}$ & $\begin{array}{r}.091 \\
(.080)\end{array}$ & $\begin{array}{l}.136^{* *} \\
(.086)\end{array}$ \\
\hline $\begin{array}{l}\text { Share Female } \\
\text { Directors }\end{array}$ & $\begin{array}{c}.001 \\
(.122)\end{array}$ & $\begin{array}{r}-.001 \\
(.122)\end{array}$ & $\begin{array}{l}.361^{\star \star \star} \\
(.067)\end{array}$ & $\begin{array}{l}346^{\star * \star} \\
(.066)\end{array}$ & $\begin{array}{l}.404^{\star \star \star} \\
(.073)\end{array}$ & $\begin{array}{l}-.002^{\star \star \star \star} \\
(.122)\end{array}$ & $\begin{array}{l}.365^{\star \star \star} \\
(.066)\end{array}$ & $\begin{array}{l}.358^{\star \star \star} \\
(.067)\end{array}$ \\
\hline $\begin{array}{l}\text { Additional Controls } \\
\text { Added }\end{array}$ & $\begin{array}{c}\text { Ln Market } \\
\text { Value, Ln } \\
\text { Employ, } \\
\text { Year, } \\
\text { Detailed } \\
\text { Occupation }\end{array}$ & $\begin{array}{l}\text { Column (1) } \\
\text { Excluding } \\
\text { CEO/Chair }\end{array}$ & $\begin{array}{l}\text { Column (2) } \\
\text { Plus } \\
\text { CEO/Chair }\end{array}$ & $\begin{array}{l}\text { Column (2) } \\
\text { Plus Detailed } \\
\text { Occupation }\end{array}$ & $\begin{array}{l}\text { Ln Market } \\
\text { Value, Ln } \\
\text { Employ, } \\
\text { Year, } \\
\text { Detailed } \\
\text { Occupation }\end{array}$ & $\begin{array}{l}\text { Column (5) } \\
\text { Excluding } \\
\text { CEO/Chair }\end{array}$ & $\begin{array}{c}\text { Column (6) } \\
\text { Plus } \\
\text { Detailed } \\
\text { Occupation }\end{array}$ & $\begin{array}{l}\text { Column (6) } \\
\text { Plus } \\
\text { Detailed } \\
\text { Occupation } \\
\text { Excluding } \\
\text { CEO/Chair }\end{array}$ \\
\hline $\mathrm{R}^{2}$ & .438 & .418 & .466 & .491 & .424 & .418 & .491 & .489 \\
\hline $\mathrm{N}$ & 31,711 & 22,700 & 31,711 & 31,711 & 31,711 & 22,700 & 31,711 & 22,700 \\
\hline
\end{tabular}

${ }^{1}$ Sources: Standard and Poor's "ExecuComp" Data, 1997-2001, IRRC Directors Data, 1997-2001..

${ }^{2}$ Total gross compensation is equal to the sum of salary, executive bonus, other annual incentive pay, longterm incentive pay, the Black-Scholes value of options granted, and the value of restricted options.

* Implies statistical significance at greater than the 90\% confidence level, ${ }^{* *} 95 \%$ confidence level, and ${ }^{* * *} 99 \%$ confidence level respectively. 
TABLE 14. FEMALE-LED FIRMS, STRUCTURE, AND PROBABILITY OF WOMEN-EXECUTIVES, 1997-2001 ${ }^{1}$

Dependent Variable: $=1$ if Woman Executive, $=0$ if Male Executive, 1997-2001

\begin{tabular}{|c|c|c|c|c|c|c|c|c|}
\hline & \multicolumn{4}{|c|}{$\begin{array}{c}\text { Female-Led is Company with Female } \\
\text { CEO, Chair or Chair/CEO }\end{array}$} & \multicolumn{4}{|c|}{$\begin{array}{l}\text { Female-Led is Company with Female } \\
\text { CEO, Chair, Chair/CEO, and Director }\end{array}$} \\
\hline Independent Variables & $\begin{array}{l}1 . \\
\text { All }\end{array}$ & $\begin{array}{l}2 . \\
\text { All }\end{array}$ & $\begin{array}{c}3 . \\
\times \text { CEO/ } \\
\text { Chair }^{2} \\
\end{array}$ & $\begin{array}{c}4 . \\
\times \text { CEO/ } \\
\text { Chair }^{2} \\
\end{array}$ & $\begin{array}{l}5 . \\
\text { All }\end{array}$ & $\begin{array}{l}6 . \\
\text { All }\end{array}$ & $\begin{array}{c}7 \\
\times \text { CEO/ } \\
\text { Chair }^{2} \\
\end{array}$ & $\begin{array}{c}8 . \\
\times \text { CEO/ } \\
\text { Chair }^{2} \\
\end{array}$ \\
\hline $\begin{array}{l}\text { Fem-Led Company } \\
\text { Dummy }\end{array}$ & $\begin{array}{l}.102^{\star \star \star} \\
(.009)\end{array}$ & $\begin{array}{l}.116^{\text {** }} \\
(.011)\end{array}$ & $\begin{array}{l}.037^{\star \star \star} \\
(.009)\end{array}$ & $\begin{array}{l}.024^{* * *} \\
(.009)\end{array}$ & $\begin{array}{l}.128^{\star \star \star} \\
(.011)\end{array}$ & $\begin{array}{l}.122^{* * *} \\
(.013)\end{array}$ & $\begin{array}{l}.048^{* * *} \\
(.011)\end{array}$ & $\begin{array}{l}.027^{\star \star \star} \\
(.010)\end{array}$ \\
\hline Share of Female Directors & $\begin{array}{l}.157^{* \star \star} \\
(.013)\end{array}$ & $\begin{array}{l}.115^{\star \star *} \\
(.012)\end{array}$ & $\begin{array}{l}.201^{* *} \\
(.016)\end{array}$ & $\begin{array}{l}.161^{\star \star \star} \\
(.017)\end{array}$ & $\begin{array}{l}.157^{\star \star \star} \\
(.013)\end{array}$ & $\begin{array}{l}.120^{\star \star \star} \\
(.012)\end{array}$ & $\begin{array}{l}.198^{\star \star *} \\
(.017)\end{array}$ & $\begin{array}{l}.161^{\star \star *} \\
(.017)\end{array}$ \\
\hline Log (Market Valuation) & & $\begin{array}{l}.002^{* *} \\
(.001)\end{array}$ & & $\begin{array}{l}.003^{* *} \\
(.001)\end{array}$ & & $\begin{array}{l}.002^{\star *} \\
(.001)\end{array}$ & & $\begin{array}{l}.003^{*} \\
(.001)\end{array}$ \\
\hline Log (Employment) & & $\begin{array}{l}-.005^{* * *} \\
(.001)\end{array}$ & & $\begin{array}{l}-.007^{* * *} \\
(.001)\end{array}$ & & $\begin{array}{l}-.005^{* * *} \\
(.001)\end{array}$ & & $\begin{array}{l}-.007^{* * *} \\
(.001)\end{array}$ \\
\hline Year Controls & & Yes & & Yes & & Yes & & Yes \\
\hline Industry Controls & & Yes & & Yes & & Yes & & Yes \\
\hline Detail Occupation Controls & & Yes & & Yes & & Yes & & Yes \\
\hline $\log L$ & $-7,540.8$ & $-6,776.4$ & $-6,694.3$ & $-6,214.1$ & $-7,539.9$ & -6.802 .2 & $-6,691.6$ & $-6,214.3$ \\
\hline $\mathrm{N}$ & 38,291 & 35,671 & 28,716 & 27,631 & 38,291 & 35,671 & 28,716 & 27,631 \\
\hline$\%$ Positive N & 5.189 & 5.453 & 6.362 & 6.467 & 5.189 & 5.453 & 6.362 & 6.467 \\
\hline
\end{tabular}

${ }^{1}$ Source: Standard and Poor's “ExecuComp" Data, 1997-2001, IRRC Directors Data, 1997-2001.

${ }^{2}$ Probit regressions exclude all executives with CEO, Chair or Chair and CEO title.

* Implies statistical significance at greater than the $90 \%$ confidence level, ${ }^{* *} 95 \%$ confidence level, and ${ }^{* \star *} 99 \%$ confidence level respectively. 